\title{
Macroinvertebrate assemblages as biological indicators of water quality in the Moiben River, Kenya
}

\author{
FO Masese , M Muchiri \& PO Raburu
}

To cite this article: FO Masese , M Muchiri \& PO Raburu (2009) Macroinvertebrate assemblages as biological indicators of water quality in the Moiben River, Kenya, African Journal of Aquatic Science, 34:1, 15-26, DOI: 10.2989/AJAS.2009.34.1.2.727

To link to this article: https://doi.org/10.2989/AJAS.2009.34.1.2.727

曲 Published online: 07 Jan 2010.

Submit your article to this journal $\pi$

Џلll Article views: 283

Q View related articles $\widetilde{ }$

4 Citing articles: 20 View citing articles 


\title{
Macroinvertebrate assemblages as biological indicators of water quality in the Moiben River, Kenya
}

\author{
FO Masese*, M Muchiri and PO Raburu \\ Department of Fisheries and Aquatic Sciences, Moi University, PO Box 1125, Eldoret, Kenya \\ *Corresponding author, e-mail: ondemasese@yahoo.com
}

Received 13 May 2008, accepted 5 December 2008

\begin{abstract}
Benthic macroinvertebrate assemblages at eight stations in the Moiben River, corresponding to different catchment land uses, were assessed in $\mathbf{2 0 0 6}$ as indicators of water quality. The relative abundance per taxon, diversity index, richness index, evenness, dominance, percentage of five dominant taxa and percentage Ephemeroptera + Plecoptera + Trichoptera (EPT) individuals were determined per sampling period per station. Significant spatio-temporal variation was observed in relative abundance, with Diptera dominating the study area. Ephemeroptera, Plecoptera and Trichoptera dominated the headwater stations, whereas Coleoptera, Oligochaeta and Chironomidae dominated further downstream. Significant relationships were recorded between physico-chemical parameters - conductivity, BOD, temperature, and discharge - and the occurrence of specific taxa, mainly Heptagenia, Caenis, Baetis, Branchiobdella, Potamon, Ilyocoris, Elmis and Chironomus. Significant changes in macroinvertebrate assemblages were primarily due to changes in water quality. As elsewhere, macroinvertebrate communities proved to be good indicators of water quality and should be used as bioindicators in long-term monitoring of this river.
\end{abstract}

Keywords: bioindicators, freshwater macroinvertebrate communities, Moiben River, water quality

\section{Introduction}

Rapid human population growth in developing countries, together with an enormous increase in the amount of waste produced, are placing demands on aquatic ecosystems. Streams and rivers continue to bear the consequences of pollution. This trend, coupled with freshwater scarcity in most countries, including Kenya (Postel 1992), continues to strain available aquatic resources. As a result these delicate ecosystems have increasingly lost their integrity, leading to sedimentation and eutrophication of the receiving water bodies such as lakes and reservoirs (Osano et al. 2003, Raburu 2003, GEF 2004).

As integrators of the effects of land-use practices within their catchments, streams and rivers can help in the diagnosis of the environmental health of the landscapes that they drain (Dallas and Day 1993). Changes anywhere on the landscape that influence rivers are reflected in the composition of resident biota (Rosenberg and Resh 1993, Harding et al. 1999). Aquatic communities are sensitive indicators of pollution as they integrate and reflect the effects of stress, both natural and human induced, over extended periods of time (Rosenberg and Resh 1993, Barbour et al. 1999). Therefore, by assessing the composition of these groups of organisms, the water quality status of streams and rivers can be determined. In so doing they act as early warning signals of pollutant loads that degrade water quality and overall ecological integrity.

Aquatic macroinvertebrates have gained prominence as bioindicators of environmental quality in lotic systems and information about their responses to changes in environmental quality continues to grow (Lenat and Crawford 1994, Baker and Sharp 1998). Their functional and structural composition varies, both spatially and temporally, in relation to environmental factors (Tate and Heiny 1995). These factors include discharge, substrate type, dissolved substances, turbidity, riparian vegetation, land use, temperature, altitude and latitude (Giller and Malmqvist 1998). However, human activities influence the effects of these factors, which in turn affects the composition and distribution of macroinvertebrates.

On the Kenyan side of the Lake Victoria basin, land-use practices are causing widespread degradation of aquatic ecosystems (Raburu 2003, GEF 2004, Okungu and Opango 2005). Increased agricultural activities in the Nzoia River Basin, (GEF 2004), the largest catchment in the Kenyan section of the Lake Victoria basin, has caused an increase in nutrient enrichment, pesticide contamination and sedimentation, not only of the streams and rivers (Osano et al. 2003) but also of Lake Victoria (Okungu and Opango 2005). In the face of changing and intensifying human activity in catchments draining into the lake, there is a need to assess the current status of water quality in the rivers and to test protocols for future monitoring. This study was therefore designed to generate information that could be used to strengthen management strategies for the Nzoia River. 


\section{Methods}

\section{Study area}

The Moiben River Basin, $35^{\circ} 06^{\prime}-35^{\circ} 34^{\prime} \mathrm{E}$ and $00^{\circ} 37^{\prime}-$ $00^{\circ} 62^{\prime} \mathrm{N}$, with an estimated area of $1050 \mathrm{~km}^{2}$ (Gok 1973) (Figure 1), is part of the upper catchment of the $12903 \mathrm{~km}^{2}$ Nzoia River watershed. The Moiben River originates on the western side of the Kerio escarpment at $2400 \mathrm{~m}$ asl. The river is approximately $81 \mathrm{~km}$ long from its source in the Kipkunnur forest to its confluence with the Kapolet River, where they join to form the larger Nzoia River (GoK 1973). The altitude of catchment boundaries in the highland areas varies between 2400 and $1500 \mathrm{~m}$ asl. The watershed has a highland equatorial climate with diverse relief features. The mean annual rainfall in the area is $1124 \mathrm{~mm}$, which occurs in one long season from March to September with two distinct peaks in May and August (Jaetzold and Schmidt 1983). The average air temperature in the region is $18^{\circ} \mathrm{C}$ during the wet season, with a maximum of $28{ }^{\circ} \mathrm{C}$ during the dry season and a minimum of $7^{\circ} \mathrm{C}$ in the coolest season. February is the hottest period, while June to July is the coldest (Jaetzold and Schmidt 1983).

The land-use systems and practices in the basin broadly range from forestry, small-scale farming to large-scale mechanised agriculture. The basin is an area of high agricultural potential and is densely populated, which influences land use. The river drains a forested area at its upper reaches before entering a valley where mixed farming is practiced. Station M1 (the most upstream sampling station) is located in a forested area (Figure 1) where human impacts are minimal. This site was therefore selected as a reference point. Other sampling stations (M2-M6) were impacted in various ways, as summarised in Table 1.

\section{Sampling design}

Triplicate samples of physico-chemical water parameters and macroinvertebrate assemblages were collected on a monthly basis at each station for six months from February to July 2006, covering part of the dry season (February to March) and part of the wet season (April to July).

\section{Physico-chemical parameters}

On each sampling occasion, physical and chemical parameters were measured before macroinvertebrates were sampled. Conductivity was measured in situ using a conductivity meter $\left(\mathrm{OAKTON}^{\circledR}\right.$, Model WD-35607-10, Singapore) while temperature and $\mathrm{pH}$ were also measured in situ by a combined $\mathrm{pH} /$ temperature-meter (OAKTON ${ }^{\circledR}$, Model $\mathrm{pH} / \mathrm{Mv} /{ }^{\circ} \mathrm{C}$ METER, Singapore). Water velocity was determined as an average of velocities taken at three points across the river by the floatation method (Herschy 1978). Water depth and width were also measured at three equallyspaced points along a $10 \mathrm{~m}$ section of river and averages were calculated, which were used in determining discharge. Discharge was then calculated as a function of crosssectional area (width $x$ depth) and water velocity. Dissolved oxygen (DO) and biological oxygen demand (BOD) were determined using the Winkler method (APHA 1992).

\section{Macroinvertebrates samples}

At each station a $100 \mathrm{~m}$ reach of stream was selected for sampling. Macroinvertebrates were collected from three microhabitats (pools, riffles and runs) that were identified according to Jeffries and Mills (1990). To avoid bias due to spatial variations or patchiness, three random samples were collected from each of the three microhabitats by establishing a transect at each sampling reach with five equally-spaced points from which a sampling point was selected using random numbers. This procedure was replicated three times for each microhabitat, making nine samples per reach. Sampling was done using a $0.09 \mathrm{~m}^{2}$ surber sampler with a $250 \mu \mathrm{m}$ mesh size and samples were pooled to make one composite sample per habitat per station. The samples were preserved in $10 \%$ formaldehyde solution prior to transporation to the laboratory for sorting.

\section{Laboratory sample processing}

In the laboratory, samples were washed through a $250 \mu \mathrm{m}$ mesh sieve, sorted, and counted using a stereo microscope. They were identified to the lowest taxomic level possible, mostly genus, according to Macan (1977), Scholtz and Holm (1985), Merritt and Cummins (1996), Nilson (1996, 1997) and Verschuren (1997); taxonomic lists of species known to be present in Kenya (e.g. Johanson 1992, Mathooko 1998) were also helpful. Voucher specimens were preserved in $75 \%$ ethanol and stored with the Moi University Department of Fisheries and Aquatic Sciences collections.

The macroinvertebrate assemblage composition was determined for each sampling station and sampling occasion using number of taxa $(S)$, total number of individuals, and relative abundance of each taxon. The Shannon-Wiener diversity index $\left(H^{\prime}\right)$ as described by Magguran (1988) was used to assess diversity as follows:

$$
H^{\prime}=\sum((n / N) \times \ln (n / N))
$$

where $n=$ number of individuals of a taxon, and $N=$ total number of individuals in the sample. An associated evenness $H^{\prime} / H_{\text {max }}^{\prime}$ (Pielou 1975) was also calculated. As an extra measure of evenness, the percentage of total numbers accounted for by the five most abundant taxa at each station was also used (Barbour et al. 1999). To assess compositional differences among sites, the percentage of intolerant taxa - Ephemeroptera + Plecoptera + Trichoptera (EPT) - which is widely used as an indicator of disturbance to stream communities (Lenat and Crawford 1994), was also calculated.

The Simpson Index $\left(D_{\mathrm{s}}\right)$ (Simpson 1949) was used as a measure of taxon richnesss. The index is given by:

$$
D_{\mathrm{S}}=\sum_{i=1}^{i=n} \frac{\left\{n_{1}\left(n_{1}-1\right)\right\}}{\{N(N-1)\}}
$$

where $n_{1}$ is the number of species in the sample and $N$ is the total number of individuals in the station. 


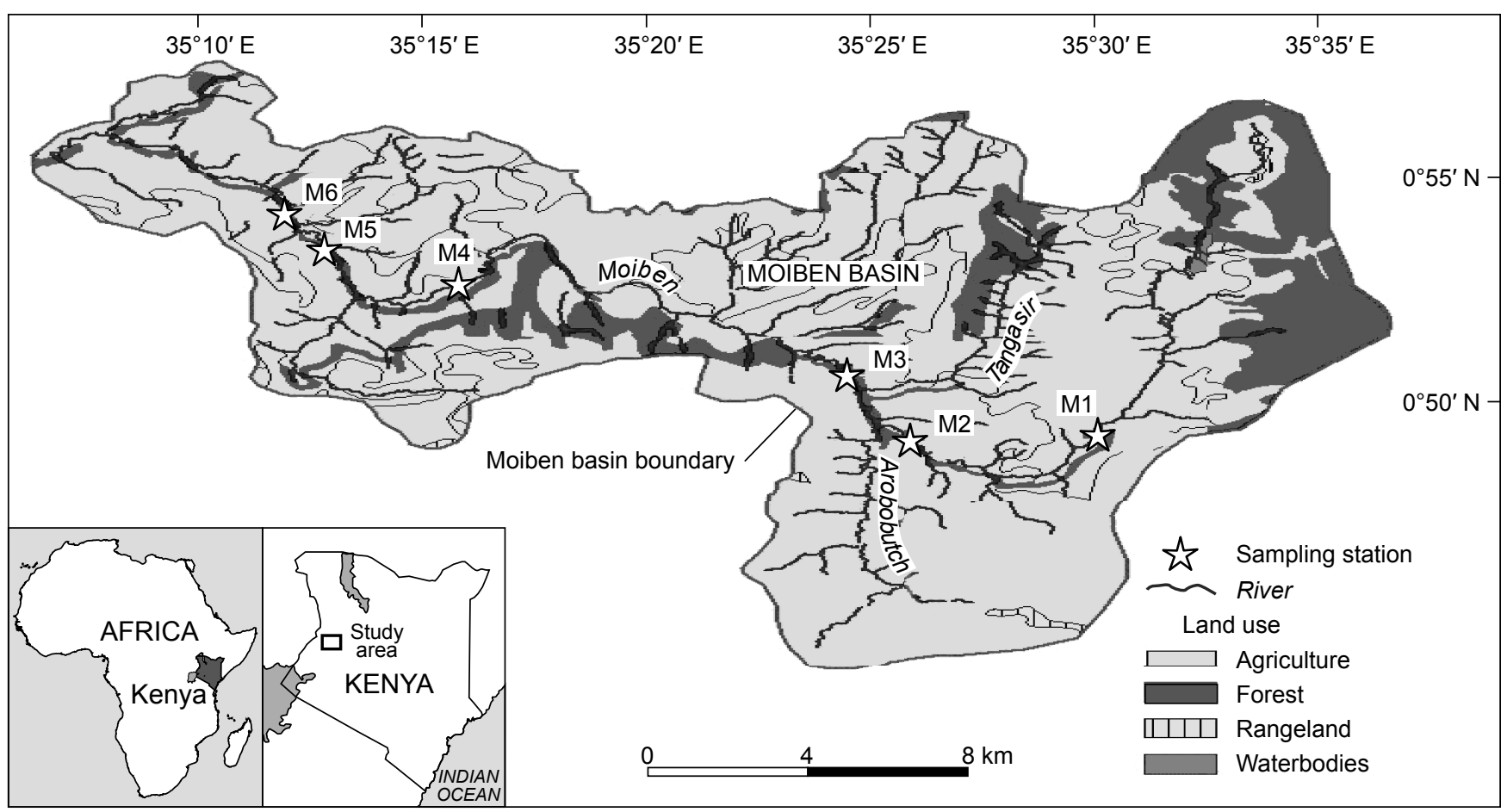

Figure 1: Land-use map of the Moiben watershed and positions of sampling stations (M1-M6) in the Moiben River

Table 1: Sampling stations along the Moiben River, with details of site characteristics and human impacts (see Figure 1 for map of localities)

\begin{tabular}{ll}
\hline Sampling station no. & Site description and land use in immediate catchment area \\
\hline M1 & The most upstream site, located in a forested area; minimal human impacts (reference site) \\
In a region with semi-intensive, small-scale mixed farming; intensive use of animals on the banks, which were \\
eroded and devoid of marginal vegetation \\
M3 and M4 & $\begin{array}{l}\text { Areas of intensive maize farming; pockets of forestry also common; Station M4 had stable banks with marginal } \\
\text { vegetation and the riparian zone was }>15 \mathrm{~m} \text { wide. } \\
\text { M5 and M6 }\end{array}$ \\
\hline
\end{tabular}

\section{Statistical analysis}

Physico-chemical parameters were expressed as means \pm SE for each sampling station. All macroinvertebrate count data were $\log _{10}(x+1)$ transformed to meet the statistical criteria for normality. One-way analysis of variance was used to test for differences between stations for each parameter. Multiple comparisons of means were done post hoc using Duncan's Multiple Range Test (DMRT) (Zar 2001) to distinguish the stations and sampling occasions that differed significantly from one another. Community indices were used to compare diversity, richness, evenness and dominance of macroinvertebrates between the different stations and sampling occasions. Pairwise Spearman's rank correlation analysis (Zar 2001) was performed to investigate the relationship between community attributes and physico-chemical parameters. Data analysis was done using SPSS for Windows (Version 13.0, SPSS Inc. Chicagio, Illinois) and all significant differences for all inference tests were accepted at $95 \%$ confidence level.

\section{Results}

\section{Physico-chemical parameters}

Mean values obtained per station for physico-chemical parameters are presented in Table 2, and temporal variability is presented in Figure 2. Conductivity, velocity, temperature, discharge and river width showed significant variation in both space and time $(p<0.05)$ while depth, DO, and BOD showed significant variation only with respect to time $(p<0.05)$. The $\mathrm{pH}$ values varied significantly $(p<0.05)$ temporally, but not spatially.

Conductivity increased downstream, with Stations M5 and M6 registering the highest values. Highly significant differences $(p<0.001)$ were observed between sampling occasions, with sampling occasion 1 (February) differing from the others. There was a general decline in conductivity over time. The lowest temperature was recorded at Station M1 and this differed from the rest of the stations. 
Table 2: Summary of the mean ( \pm SE) physico-chemical properties of the study stations on the Moiben River, February-July 2006

\begin{tabular}{|c|c|c|c|c|c|c|}
\hline & \multicolumn{6}{|c|}{ Station } \\
\hline & M1 & M2 & M3 & M4 & M5 & M6 \\
\hline Air temperature $\left({ }^{\circ} \mathrm{C}\right)$ & $23.3 \pm 2.8$ & $25 \pm 2.2$ & $23.6 \pm 3.3$ & $23.7 \pm 0.8$ & $25.2 \pm 2.2$ & $25.0 \pm 2.7$ \\
\hline Water depth $(\mathrm{m})$ & $0.3 \pm 0.08$ & $0.4 \pm 0.13$ & $0.3 \pm 0.1$ & $0.6 \pm 0.21$ & $0.5 \pm 0.15$ & $0.6 \pm 0.24$ \\
\hline Width $(\mathrm{m})$ & $2.6 \pm 0.2$ & $3.3 \pm 0.4$ & $7.5 \pm 0.5$ & $4.5 \pm 0.3$ & $5.8 \pm 0.8$ & $4.3 \pm 0.2$ \\
\hline Current velocity $\left(\mathrm{m} \mathrm{s}^{-1}\right)$ & $0.5 \pm 0.07$ & $0.6 \pm 0.05$ & $0.5 \pm 0.07$ & $0.6 \pm 0.07$ & $0.7 \pm 0.09$ & $0.7 \pm 0.09$ \\
\hline $\mathrm{pH}$ & $9.4 \pm 0.4$ & $9.2 \pm 0.7$ & $8.8 \pm 0.3$ & $9.9 \pm 0.7$ & $9.7 \pm 0.5$ & $10.6 \pm 0.4$ \\
\hline Dissolved oxygen $\left(\mathrm{mg} \mathrm{l}^{-1}\right)$ & $7.6 \pm 0.5$ & $7.8 \pm 0.1$ & $7.1 \pm 0.8$ & $6.8 \pm 0.9$ & $7.3 \pm 0.5$ & $7.32 \pm 0.5$ \\
\hline $\mathrm{DO}$ (\% saturation) & $78.6 \pm 5.4$ & $82.2 \pm 1.6$ & $75.6 \pm 8.0$ & $71.4 \pm 8.8$ & $81.1 \pm 6.5$ & $79.95 \pm 3.8$ \\
\hline $\mathrm{BOD}\left(\mathrm{mg} \mathrm{l}^{-1}\right)$ & $1.4 \pm 0.3$ & $2.1 \pm 0.5$ & $1.6 \pm 0.6$ & $1.8 \pm 0.5$ & $2.4 \pm 0.4$ & $2.2 \pm 0.4$ \\
\hline Conductivity $\left(\mu \mathrm{S} \mathrm{cm}^{-1}\right)$ & $70.3 \pm 16.6$ & $83.6 \pm 15.1$ & $110.5 \pm 20.3$ & $113.2 \pm 12.7$ & $150.7 \pm 18.3$ & $178.7 \pm 27.7$ \\
\hline
\end{tabular}

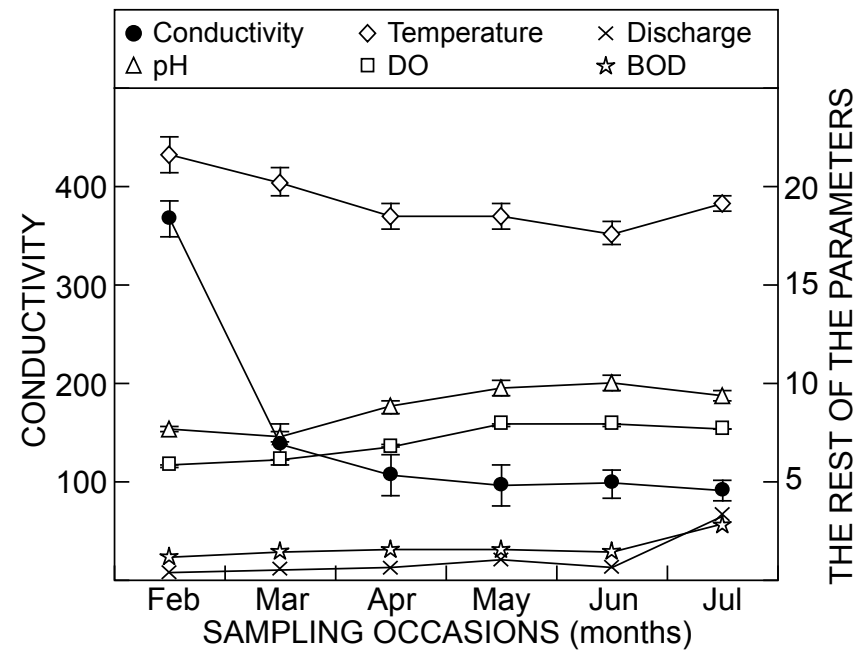

Figure 2: Monthly variation (mean $\pm \mathrm{SE}$ ) in physico-chemical parameters in the Moiben River during the study period, FebruaryJuly 2006. February and March $=$ dry season, April to July = rainy season (units of measurement for 'Rest of parameters': temperature $\left({ }^{\circ} \mathrm{C}\right)$; $\mathrm{pH}$ (no units); DO (mg 1-1); discharge $\left(\mathrm{m}^{3} \mathrm{~s}^{-1}\right)$; $\mathrm{BOD}\left(\mathrm{mg} \mathrm{l}^{-1}\right)$

The highest temperature was recorded during February and the lowest in July. The highest $\mathrm{pH}$ value was recorded in June 2006 and the lowest in February 2006. The lowest DO was also recorded during February and this differed from the rest of the sampling occasions $(p<0.05)$. In terms of BOD, Station M1 recorded the lowest value and this differed only from Station M5, which recorded the highest value $(p<0.05)$. With respect to time, the highest BOD was recorded on the last sampling occasion (July); this value was significantly different from those measured during all other sampling occasions $(p<0.05)$.

\section{Macroinvertebrate assemblages}

A total of 7333 macroinvertebrate specimens were collected, comprising 70 taxa belonging to 13 orders and 50 families (see Appendix). The relative abundance of taxonomic groups encountered is shown in Figure 3. Diptera was the

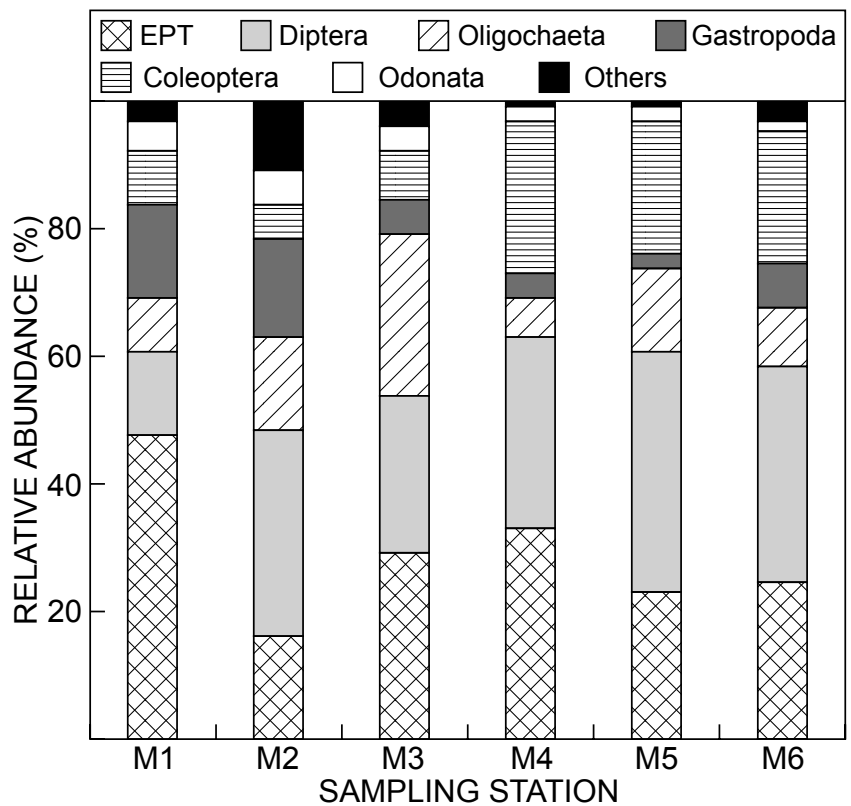

Figure 3: Relative abundance of the main taxonomic groups of macroinvertebrates at each sampling station from February to July 2006

commonest order in the study area, occurring at all stations. Other orders that were sampled at all stations included Ephemeroptera, Coleoptera, Oligochaeta, Trichoptera, Gastropoda, Odonata and Hemiptera. There were significant differences in abundance between the stations and the sampling periods $(p<0.001)$.

Station M1 had the highest mean abundance per sample $(291.7 \pm 63.5)$ while Station M6 had the lowest $(128.5 \pm 34.1)$ (Figure 4). A general downstream decline in mean abundance per sample was observed, except at Station M4. There was an increase in the number of genera in the middle stations with Station M4 recording the highest (41) and Station M6 (31) recording the lowest (Figure 4). Plecoptera were not represented at Stations M2 or M3 (Table 2). Hirudinea occurred at Stations M1, M2 and M5, while Crustacea did not occur at Station M6. Arachnida 


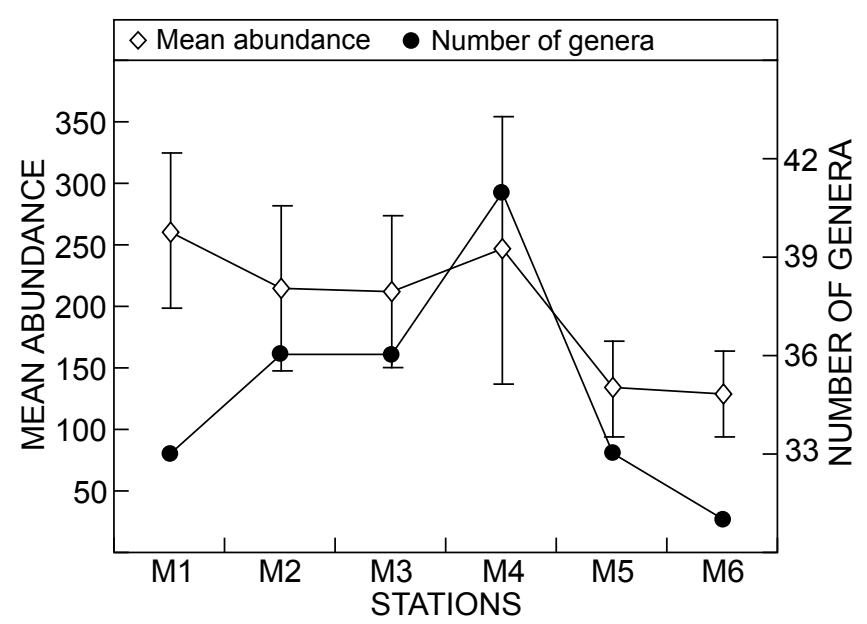

Figure 4: Spatial variation $( \pm S E)$ in mean abundance and number of genera (per $0.09 \mathrm{~m}^{2}$ ) among the sampling stations during February to July 2006

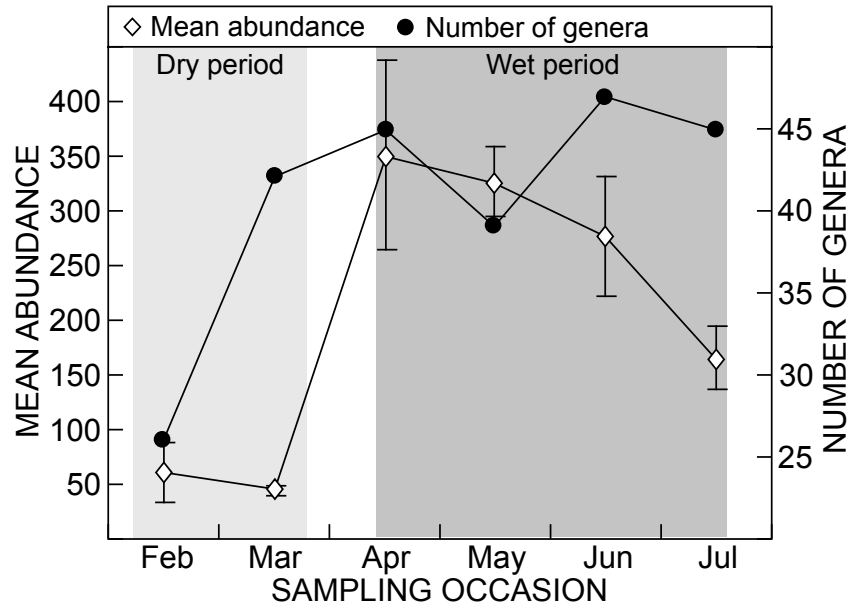

Figure 5: Temporal variation $( \pm S E)$ in mean abundance and number of genera (per $0.09 \mathrm{~m}^{2}$ ) among the sampling occasions during February to July 2006

Table 3: The diversity measures $( \pm \mathrm{SE})$ of macroinvertebrate communities at the study stations on the Moiben River, February-July 2006

\begin{tabular}{|c|c|c|c|c|c|c|}
\hline \multirow[b]{2}{*}{ Community attributes } & \multicolumn{6}{|c|}{ Station } \\
\hline & 1 & 2 & 3 & 4 & 5 & 6 \\
\hline Dominance & $0.13 \pm 0.01$ & $0.15 \pm 0.01$ & $0.19 \pm 0.03$ & $0.15 \pm 0.2$ & $0.32 \pm 0.11$ & $0.18 \pm 0.03$ \\
\hline Diversity index $\left(H^{\prime}\right)$ & $2.54 \pm 0.1$ & $2.15 \pm 0.1$ & $2.16 \pm 0.1$ & $2.24 \pm 0.1$ & $1.9 \pm 0.2$ & $2.1 \pm 0.1$ \\
\hline Evenness index & $0.46 \pm 0.05$ & $0.46 \pm 0.05$ & $0.78 \pm 0.4$ & $0.48 \pm 0.06$ & $0.41 \pm 0.03$ & $0.46 \pm 0.03$ \\
\hline$\% 5$ most dominant taxa & 95.45 & 87.98 & 91.07 & 92.75 & 94.0 & 89.46 \\
\hline
\end{tabular}

were sampled only at Stations M2 and M3 while Lepidoptera occurred only at Station M1 (see Table 1 for a description of these sampling stations).

With respect to temporal variation in abundance, results from February and March differed from those of April and May, when the highest mean abundances were obtained (Figure 5), but results from June and July did not differ from either of these groups. The number of genera encountered was lowest on the first sampling occasion (February), then rose during March and April, declined in May, rose to its highest levels in June, and then declined slightly in July (Figure 5). During the dry period (February and March) low numbers of pollution-sensitive EPT were collected, while the numbers of pollution-tolerant taxa such as Oligochaeta, Gastropoda and Diptera were very high. As the rains started and increased a succession was evident: EPT, Coleoptera, Hemiptera and Odonata taxa and abundances increased while the abundances of Oligochaeta, Gastropoda and Diptera declined. However, there was an overall decrease in abundance for all taxa during the heavy rains (June and July).

Community attribute results at each sampling site (described in Table 1) are presented in Table 3. The Shannon-Wiener diversity index was highest at Station M1 followed by Station M4 while Station M5 had the lowest value. The evenness index was highest at Station M3 and lowest at Station M5. Mean taxon richness was highest at Station
M1 ith $9.67 \pm 1.6$ followed by Station M4 with $8.4 \pm 1.6$ while the lowest was recorded at Station M5 with $6.16 \pm 1.1$. The percentage of the five most dominant taxa was highest at Station M1 with $95.5 \%$ while it was lowest at Station M2 with $88 \%$. There were significant differences in relative abundance of EPT spatially $(p<0.05)$ but not temporally. Of the total abundance of macroinvertebrate individuals collected at Station M1, $52.2 \%$ belonged to the EPT while a general decline was observed downstream (Table 3).

Relationship between physico-chemical parameters, macroinvertebrate abundance and community attributes

Table 4 shows pairwise Spearman's rank correlations between physico-chemical parameters and macroinvertebrate community attributes. Altitude was negatively correlated with temperature, conductivity, depth, width and discharge, but was positively correlated with abundance $(p<0.05)$. Abundance was negatively correlated with most of the physico-chemical parameters considered, except altitude and $\mathrm{pH}$. Macroinvertebrate abundance was lowest during the dry period in February. It increased progressively during the onset of the rainy season but started to decline during the peak and spates in May. During this period the river was characterised by large quantities of suspended matter and high sediment loads. Discharge had also increased more than ten times. Taxon richness was negatively correlated with 
Table 4: Spearman's rank correlation coefficients observed among physico-chemical parameters, and between physico-chemical parameters and selected taxa and community structure attributes. Units are identical to those in Table $2\left({ }^{*}=\right.$ significant correlation at $\left.p=0.05\right)$

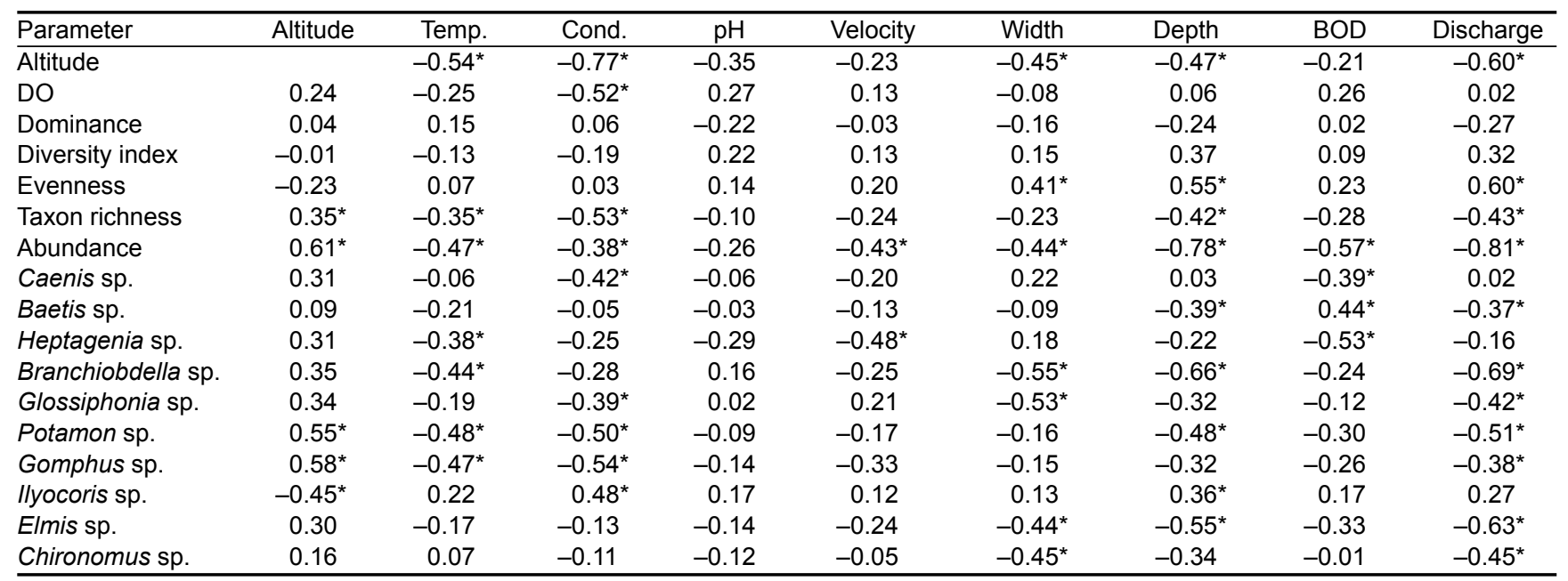

water temperature, conductivity, depth, BOD and discharge, while it was positively correlated with altitude $(p<0.05)$. Evenness showed a positive relationship with width, depth and discharge.

Among the macroinvertebrate taxa, Caenis sp. exhibited a negative relationship with conductivity and BOD. Baetis sp. displayed a negative relationship with depth and discharge but a positive relationship with BOD. Heptagenia sp. showed a negative relationship with temperature, velocity and BOD. Branchiobdella sp. exhibited negative relationships with temperature, width, depth and discharge. Eriocheir sp. and Gomphus sp. both showed a negative relationship with temperature, conductivity and discharge, but were positively correlated with altitude. Ilyocoris sp. was positively correlated with conductivity and depth, but negatively with altitude. Elmis sp. showed a negative relationship with width, depth and discharge. Chironomus sp. was negatively correlated with width and discharge. Intolerant taxa were negatively correlated with BOD. Discharge influenced most taxa negatively, by reducing their abundance.

\section{Discussion}

\section{Physico-chemical variables}

The spatial differences in mean BOD along the river could be explained by changes in human activity. The water clarity was very high upstream and it was possible to see the stream bottom, but further downstream there was an accumulation of sediments and other wastes that resulted in higher BOD values, which reached its peak at Station M6. The lowest BOD values, obtained at Station M1, could be attributed to low sedimentation as a result of minimal human impacts. An increase in BOD that registered a peak in July during the rainy season, might have been caused by increased runoff, which transports organic matter and sediments from the catchment into the river (Morris et al. 2003).

The uniformity of DO along the river must have been the result of the mixing of water caused by a significant drop in altitude between the stations (Busulwa and Bailey 2004). Significant differences recorded between the sampling periods could have resulted from changes in water velocity resulting from varying discharge rates.

Water temperature showed both spatial and temporal variation. The significantly lower temperature recorded at Station M1 was due to good riparian vegetation cover at that station. Vegetation cover limits solar radiation reaching the water thus contributing to minimal fluctuations of temperature (Giller and Malmqvist 1998). High temperature during the first sampling period was due to high solar radiation caused by lack of cloud cover and low water volume during the dry period.

The water chemistry differed temporally with respect to most parameters. Conductivity, DO and BOD, which were positively correlated with river width, depth, water velocity and discharge, showed significant variation between the dry and rainy seasons. These findings can be attributed to seasonal effects of non-point sources of pollution, which are mobilised during the rainy season through runoff and leaching, especially from agricultural areas (Sundblad et al. 1994, Moreau et al. 1998, Huber et al. 2000).

\section{Spatio-temporal variations in composition, distribution and community structure}

Diptera and Ephemeroptera dominated the study area, accounting for more than 59 per cent of all taxa by numbers. Similar findings have been obtained in highland tropical streams. For instance, Mathooko and Mavuti (1992), while investigating Mount Kenya streams, found the benthic communities to be dominated by Baetis sp. (Ephemeroptera: Baetidae) and Simulium sp. (Diptera: Simuliidae). Similar results were obtained in studies carried out in the Njoro River, Kenya where Kibichii et al. (2007) found that Baetis sp. and Simuliidae comprised 69 per cent, by number, of all benthic taxa identified.

Despite the overall dominance of Baetidae and Simuliidae, marked changes in relative abundance of various taxa were observed downstream. Headwater stations were dominated 
by taxa associated with pristine waters and by pollutionsensitive macroinvertebrates such as Ephemeroptera, Plecoptera and Trichoptera, which declined downstream. In Stations M2 and M3 pollution-sensitive taxa were replaced by Chironomus sp., Hydropsyche sp., Simulium sp., Baetis sp., Elmidae and Oligochaeta. The high numbers of these taxa can be attributed to organic pollution as a result of enrichment and sedimentation caused by agricultural activities and excretion by livestock in the riparian areas (Buss et al. 2002). High nutrient enrichment and sedimentation have been shown to favour some Chironomidae, net-spinning Trichoptera, Mollusca and Oligochaeta at the expense of Ephemeroptera and Plecoptera (Quinn et al. 1997). Stations $\mathrm{M} 1$ and M2 are devoid of riparian vegetation cover and are used as watering points for animals, thus receiving higher amounts of animal and agricultural wastes, compared to Station M1 located in an area with a well-protected riparian zone with limited animal access and other human activities. Chironomus sp. dominated Stations M5 and M6 that were characterised by increased animal use in the riparian zones and other human activities like washing, bathing and sand mining. Chironomus sp. are known to occur in greater abundance in areas with environmental stress as the genus is able to colonise water with low oxygen concentration because they are able to use haemoglobin as a means of respiring more efficiently during these low-oxygen conditions (Johnson et al. 1993).

High diversity of macroinvertebrates was obtained at Station M4 despite there being point and non-point sources of pollution upstream. This station had well-protected banks with vegetation cover that offered wider habitat diversity to aquatic biota. This explains the high abundance and taxon richness at this station as compared to other stations downstream. This observation concurs with Ruburu's findings during his studies carried out at the Nyando River, where high macroinvertebrate diversity recorded below point sources of pollution was attributed to riparian vegetation cover and instream habitat quality (Raburu 2003).

Apart from anthropogenic impacts, natural stress such as spates and floods may also influence macroinvertebrate assemblage distribution in the tropics. In this study temporal differences in taxon richness and abundance were recorded between the dry and rainy seasons. Low taxon richness was recorded during the dry period and at the onset of the rains and a significant reduction in abundance was recorded during the long rainy season and during spates in July. This was consistent with the findings of Shivoga (200I) in two tropical streams in Kenya where macroinvertebrate abundance was highest at the onset of the rains and declined progressively as the rainfall increased. Although natural conditions influence taxon richness and abundance, in the current study it seems likely that human activities exacerbated the effects of these conditions, leading to the observed distribution and abundance of the various taxa. For instance, land-use activities - relating to road building, agriculture and settlements - influence the quantity of runoff and sediments that enter streams and rivers during the rains (Wang and Lyons 2003); lower runoff levels mean that lower volumes of sediments and nutrients from disturbed land surfaces enter streams. However, during the peak of the dry season, conditions can worsen in streams and rivers because, as discharge declines, $\mathrm{pH}$ also declines (as recorded in North American streams: Bowman et al. 2006), temperatures rise and dissolved oxygen becomes limiting. This scenario can explain the temporal and spatial variation in taxon richness, composition and abundance of macroinvertebrates in the study area.

There was no clear trend in taxon richness with distance downstream. Stations at the upper reaches of the river had lower numbers of genera, which increased at Station M4 and then decreased at the lower stations. This is the trend expected in most riverine systems (Vannote et al. 1980) as they reflect changes in stream order and other factors that influence community composition and structure. On the other hand, high diversity at Station M1 can be attributed to good habitat quality and high water quality in the upper reaches of the Moiben River. The forests surrounding Station M1 were a good source of allochthonous organic matter for stream biota. Canopy cover at this station helped maintain low water temperatures and provided diverse habitats for a variety of macroinvertebrates, leading to increased diversity. However, the downstream decrease in diversity can be linked to agricultural land-use intensification in downstream catchment areas (Wang and Lyons 2003).

Ecologically-unimpaired stations could be separated from impaired ones by assessing the composition of their EPT. For instance, the relative abundance of EPT at pristine Station M1 was $53.1 \%$ as compared to Stations M2 and M5 with $17.5 \%$ and $23.2 \%$ respectively, both with degraded riparian zones and instream habitats. This concurs with other studies (Lemly 1982, Baker and Sharp 1998, Raburu 2003) in which low relative abundances of EPT were observed in degraded areas. Despite the sensitivity of Plecoptera to pollution, their representation in the current study area was low, compared to that of Ephemeroptera and Trichoptera. With only two taxa and a total of 20 individuals sampled in the whole study area, plus their absence at Stations M2 and M3, their use as indicators of water quality in the current study area is Imited. Similar low numbers in tropical streams have also been reported (Thorne and Williams 1997). Durand and Leveque (1981), cited in Thorne and Williams (1997), reported only one plecopteran species in the whole of West Africa. However, this order was well-represented in the Nyando River, Lake Victoria basin in Kenya (Raburu 2003) where it formed a larger fraction of the percentage EPT than in the current study. Their low number of genera and abundance in the Moiben River can, therefore, be attributed to degradation. The instream habitats in the Moiben River comprise mostly sandy and muddy bottoms known to affect plecopteran distribution, diversity and abundance (Lemly 1982).

Overall, this study revealed that macroinvertebrate communities responded to changes in water quality along the river. Despite little apparent change in taxon richness observed at the different stations, there were marked shifts in dominance and composition. Headwater stations were dominated by taxa associated with pristine or unimpacted waters with a decrease in the pollution-intolerant genera, like EPT, downstream. An increase in the fraction of Diptera and Oligochaeta downstream also indicated a decline in water quality. This response is a clear indication that macroinvertebrate communities in the 
river are good candidates for assessing water quality and general ecosystem integrity. With intensification of agricultural activities in the watershed there is a need to consider macroinvertebrate assemblages in future water quality monitoring programs in the river. To date, biomonitoring protocols using macroinvertebrates have not been developed in Kenya, and since this approach is cost effective, we strongly recommend that this be incorporated in the continuous monitoring of surface water quality.

Acknowledgements - Financial support for this project came mainly from USAID Grant No. LAG-G-00-96-90015-00 through the Pond Dynamics/Aquaculture Collaborative Research Support Program. The Aquaculture CRSP accession number is 1364 . The opinions expressed herein are those of the author(s) and do not necessarily reflect the views of the US Agency for International Development. Our thanks go also to Messrs Isaac Ebenyo, Lubanga Lunaligo and William Kinyua, all of whom assisted us in one way or another during the fieldwork.

\section{References}

Allan JD. 1995. Stream ecology: structure and function of running waters. Boston: Kluwer Academic Press.

APHA (American Public Health Association). 1992. Standard methods for the examination of water and wastewater (19th edn). Washington, DC: American Public Health Association, American Water Works Association, and Water Pollution Control Federation.

Baker SC, Sharp HF. 1998. Evaluation of the recovery of a polluted urban stream using Ephemeroptera-Plecoptera-Trichoptera Index. Journal of Freshwater Ecology 13: 229-234.

Barbour MT, Gerritsen J, Snyder BD, Stribling JB. 1999. Rapid bioassessment protocols for use in wadeable streams and rivers: periphyton, benthic invertebrates, and fish (2nd edn). Washington DC: US Environmental Protection Agency, Office of Water. Report EPA 841-B-99-002.

Bowman MT, Keith MS, Reid RA, Scott LD. 2006. Temporal response of stream benthic macroinvertebtrate communities to the synergistic effects of anthropogenic acidification and natural drought events. Freshwater Biology 51: 768-782.

Buss DF, Baptista DF, Silveira MP, Nessimian JL, Dorville LFM. 2002. Influence of water chemistry and environmental degradation on macroinvertebrate assemblages in a river basin in south-east Brazil. Hydrobiologia 481: 125-136.

Busulwa HS, Bailey RG. 2004. Aspects of the physico-chemical environment of the Rwenzori Rivers, Uganda. African Journal of Ecology 42: 87-92.

Dallas HF, Day JA. 1993. The effect of water quality variables on riverine ecosystems: a review. Pretoria: Water Research Commission. WRC Report No. TT 61/93.

GEF (Global Environmental Facility). 2004. Western Kenya integrated ecosystem project; Executive Summary. Available at http://www.gefweb.org/Documents/Council-Documents/-C23/ MFA-Kenya-Executivesummary [accessed July 2007].

Giller PS, Malmsqvist B. 1998. The biology of streams and rivers New York: Oxford University Press.

GoK (Government of Kenya). 1973. Topographical maps of Kenya, series Y503, edition 3-SK. Survey of Kenya, sheet NA-36-16.

Harding JS, Young RG, Hayes JW, Shearer KA, Stark JD. 1999. Changes in agricultural intensity and river health along a river continuum. Freshwater Biology 42: 345-357.

Herschy RW (ed.). 1978. Hydrometry, principles and practices. Chichester: John Wiley \& Sons.
Huber A, Bach M, Frede HG. 2000. Pollution of surface water with pesticides in Germany: modelling non-point source inputs. Agriculture, Ecosystems and Environment 80: 191-204.

Jaetzold R, Schmidt H. 1983. Farm management handbook of Kenya: natural conditions and farm management information central Kenya, Vol. II/B. Nairobi: Ministry of Agriculture, Kenya, in cooperation with the Germany Agricultural Team (GAT) of the Germany Agency for Technical Cooperation (GTZ).

Jeffries M, Mills D. 1990. Freshwater ecology principles and applications. London: Belhaven Press.

Johanson KA. 1992. A catalogue of the caddisflies of East Africa (Insecta, Trichoptera). Steenstrupia 18: 113-141.

Johnson RK, Wiederhoum T, Rosenberg DM. 1993. Freshwater biomonitoring using individual organisms, populations and species assemblages of benthic macroinvertebrates. In: Rosenberg DM, Resh VH (eds), Freshwater biomonitoring and benthic macroinvertebrates. New York: Chapman \& Hall. pp 40-158.

Karr JR. 1992. Ecological integrity: protecting Earth's life-support systems. In: Costanza R, Norton BG, Haskell BJ (eds), Ecosystem health; new goals for environmental management. Washington, DC: Island Press. pp 223-238.

Kibichii S, Shivoga WA, Muchiri M, Miller SN. 2007. Macroinvertebrate assemblages along a land-use gradient in the upper River Njoro watershed of Lake Nakuru drainage basin, Kenya. Lakes \& Reservoirs: Research and Management 12: 107-117.

Lemly AD. 1982. Modification of benthic insect communities in polluted streams: combined effects of sedimentation and nutrient enrichment. Hydrobiologia 87: 229-246.

Lenat DR, Crawford JK. 1994. Effects of land use on water quality and aquatic biota of three North American piedmont streams. Hydrobiologia 294: 185-199.

Macan TT. 1977. A guide to freshwater invertebrate animals. London: Longman.

Magguran A. 1988. Ecological diversity and its measurement. London: Croom Helm.

Mathooko JM. 1998. Mayfly diversity in East Africa. African Journal of Ecology 36: 368-370.

Mathooko JM, Mavuti KM. 1992. Composition and seasonality of benthic invertebrates and drift in the Naro Moru River, Kenya. Hydrobiologia 232: 47-56.

Merritt RW, Cummins KW. 1996. An introduction to the aquatic insects of North America (3rd edn). Dubuque: Kendall Hunt.

Moreau S, Bertu G, Buson C. 1998. Seasonal and spatial trends in nitrogen and phosphorous loads to the upper catchment of River Valaine: relationships with land-use. Hydrobiologia 374: 247-258.

Morris CC, Jawyer JA, Bennet HH, Robinson CD. 2003. Effects of sediment quality on the health of aquatic ecosystems: a case study on depth of fines in coastal plain streams in Alabama. In: Simon TP (ed.), Biological response signatures: indicator patterns using aquatic communities. Boca Raton: CRC Press. pp 113-120.

Nilson A (ed.). 1996. Aquatic insects of north Europe; a taxonomic handbook, vol 1: Ephemeroptera-Plecoptera-HeteroteraNeuroptera-Megaloptera-Coleoptera-Trichoptera-Lepidoptera. Stenstrup: Apollo Books.

Nilson A (ed.). 1997. Aquatic insects of north Europe; a taxonomic handbook, vol. 2: Odonata-Diptera. Stenstrup: Apollo Books.

Okungu J, Opango P. 2005. Pollution loads into Lake Victoria from the Kenyan catchment. In: Mallya CA (ed.), Knowledge and experiences gained from managing the Lake Victoria ecosystem. Dar es Salaam: Regional Secretariat, Lake Victoria Environmental Management Project (LVEMP). pp 90-108.

Osano O, Nzyuko D, Admiraal W. 2003. The fate of 
chloroacetalinide herbicides and their degradation products in the Nzoia Basin, Kenya. Ambio 32: 424-427.

Pielou EC. 1975. Ecological diversity. New York: Wiley \& Sons.

Postel S. 1992. The last oasis: facing water scarcity. Worldwatch environmental series. London: Earthscan publications.

Quigley M. 1977. Invertebrates of streams and rivers: a key to identification. London: Edward Arnold.

Quinn JM, Cooper AB, Davies-Colley RJ, Rutherford JC, Williamson RB. 1997. Land-use effects on habitat, water quality, periphyton, and benthic macroinvertebrates in Waikato, New Zealand, hill-country streams. New Zealand Journal of Marine and Freshwater Research 32: 579-597.

Raburu PO. 2003. Water quality and the status of aquatic macroinvertebrates and ichthyofauna in River Nyando, Kenya. $\mathrm{PhD}$ thesis, Moi University, Kenya.

Rosenberg DM, Resh VH. 1993. Introduction to freshwater biomonitoring and benthic macroinvertebrates. In: Rosenberg DM, Resh VH (eds), Freshwater biomonitoring and benthic macroinvertebrates. New York: Chapman \& Hall. pp 1-9.

Scholtz CH, Holm E. 1985. Insects of southern Africa. Durban: Butterworths.

Shivoga WA. 2001. The influence of hydrology on the structure of invertebrate communities in two streams flowing into Lake Nakuru, Kenya. Hydrobiologia 458: 121-130.
Simpson EH. 1949. Measurement of diversity. Nature 163: 688

Sundblad K, Tonderski A, Rulewski J. 1994. Nitrogen and phosphorous in the Vistula River, Poland - changes from source to mouth. Water Science and Technology 30: 177-186.

Tate CM, Heiny JS. 1995. The ordination of benthic invertebrate communities in the South Platte river basin in relation to environmental factors. Freshwater Biology 33: 439-454.

Thorne RSJ, Williams WP. 1997. The response of benthic macroinvertebrates to pollution in developing countries: a multimetric system of bioassessment. Freshwater Biology 37: 671-686.

Vannote RL, Minshall GW, Cummins KW, Sedell JR, Cushing CE. 1980. The River Continuum concept. Canadian Journal of Fisheries and Aquatic Sciences 37: 130-137.

Verschuren D. 1997. Taxonomy and ecology of subfossil Chironomidae (Insecta: Diptera) from Rift Valley lakes in central Kenya. Archives of Hydrobiology 107: 467-512.

Wang L, Lyons J. 2003. Fish and benthic macroinvertebrate assemblage as indicators of stream degradation in urbanizing watersheds. In: Simon TP (ed.), Biological response signatures: indicator patterns using aquatic communities. Boca Raton: CRC Press. pp 113-120.

Zar JH. 2001. Biostatistical analysis. Englewood Cliffs: Prentice Hall. 
Appendix: Occurrence of macroinvertebrate taxa at six stations on the Moiben River, February to July 2006 (* $=$ occurrence)

\begin{tabular}{|c|c|c|c|c|c|c|}
\hline \multirow{2}{*}{ Taxon } & \multicolumn{6}{|c|}{ Station } \\
\hline & M1 & M2 & M3 & M4 & M5 & M6 \\
\hline \multicolumn{7}{|l|}{ Ephemeroptera } \\
\hline \multicolumn{7}{|l|}{ Baetidae } \\
\hline Baetis sp. & * & * & * & * & * & * \\
\hline Acentrella sp. & - & - & - & * & - & - \\
\hline \multicolumn{7}{|l|}{ Caenidae } \\
\hline Caenis sp. & * & * & * & * & * & * \\
\hline \multicolumn{7}{|l|}{ Ephemeridae } \\
\hline Ephemera sp. & - & - & - & * & * & * \\
\hline \multicolumn{7}{|l|}{ Heptageniidae } \\
\hline Heptagenia sp. & * & * & * & * & * & * \\
\hline Rhithrogena sp. & - & * & * & - & - & * \\
\hline \multicolumn{7}{|l|}{ Oligoneuridae } \\
\hline Lachlania sp. & * & - & - & - & - & - \\
\hline \multicolumn{7}{|l|}{ Plecoptera } \\
\hline \multicolumn{7}{|l|}{ Nemouridae } \\
\hline Nemoura sp. & * & - & - & * & - & * \\
\hline \multicolumn{7}{|l|}{ Perlodidae } \\
\hline Neoperla sp. & * & - & - & - & * & * \\
\hline \multicolumn{7}{|l|}{ Trichoptera } \\
\hline Hydroptilidae & * & - & - & * & * & - \\
\hline Leptoceridae & * & * & - & - & - & - \\
\hline Polycentropodidae & * & * & - & * & - & - \\
\hline \multicolumn{7}{|l|}{ Hydropsychidae } \\
\hline Hydropsyche sp. & * & * & * & * & * & * \\
\hline \multicolumn{7}{|l|}{ Psychomyiidae } \\
\hline Lype sp. & - & * & - & - & - & - \\
\hline Phryganeidae & & & & & & \\
\hline Lepidostoma sp. & - & - & - & * & - & - \\
\hline Philopotamidae & & & & & & \\
\hline Philopotamus sp. & - & - & * & * & - & - \\
\hline Hirudinea & & & & & & \\
\hline Erpobdellidae & & & & & & \\
\hline Erpobdella sp. & - & - & * & - & - & \\
\hline Glossiphonidae & & & & & & \\
\hline Branchiobdella sp. & * & * & * & - & * & * \\
\hline Glossiphonia sp. & * & * & - & * & * & - \\
\hline Hellobdella sp. & - & * & - & - & - & - \\
\hline Oligochaeta & & & & & & \\
\hline Lumbricidae & & & & & & \\
\hline Lumbricus sp. & * & * & * & * & * & * \\
\hline Gastropoda & & & & & & \\
\hline Limnaeidae & & & & & & \\
\hline Limnaea sp. & * & - & - & * & - & - \\
\hline Planorbiidae & & & & & & \\
\hline Planorbis sp. & * & * & * & * & * & * \\
\hline Sphaeriidae & & & & & & \\
\hline Pisidium sp. & * & * & * & * & * & * \\
\hline Sphaerium sp. & * & * & - & - & * & - \\
\hline Unionidae & & & & & & \\
\hline Anodonta sp. & - & - & - & - & - & * \\
\hline Crustacea & & & & & & \\
\hline Decapoda & & & & & & \\
\hline Eriocheir sp. & * & * & * & * & * & - \\
\hline Arachnida & - & * & * & - & - & - \\
\hline Odonata & & & & & & \\
\hline Coenagrionidae & & & & & & \\
\hline Enallagma sp. & & * & * & * & * & * \\
\hline Gomphidae & & & & & & \\
\hline Gomphus sp. & * & * & * & * & * & - \\
\hline Epertogomphus sp. & * & * & * & - & - & - \\
\hline Aeshna sp. & - & * & * & * & * & * \\
\hline
\end{tabular}


Appendix: (cont.)

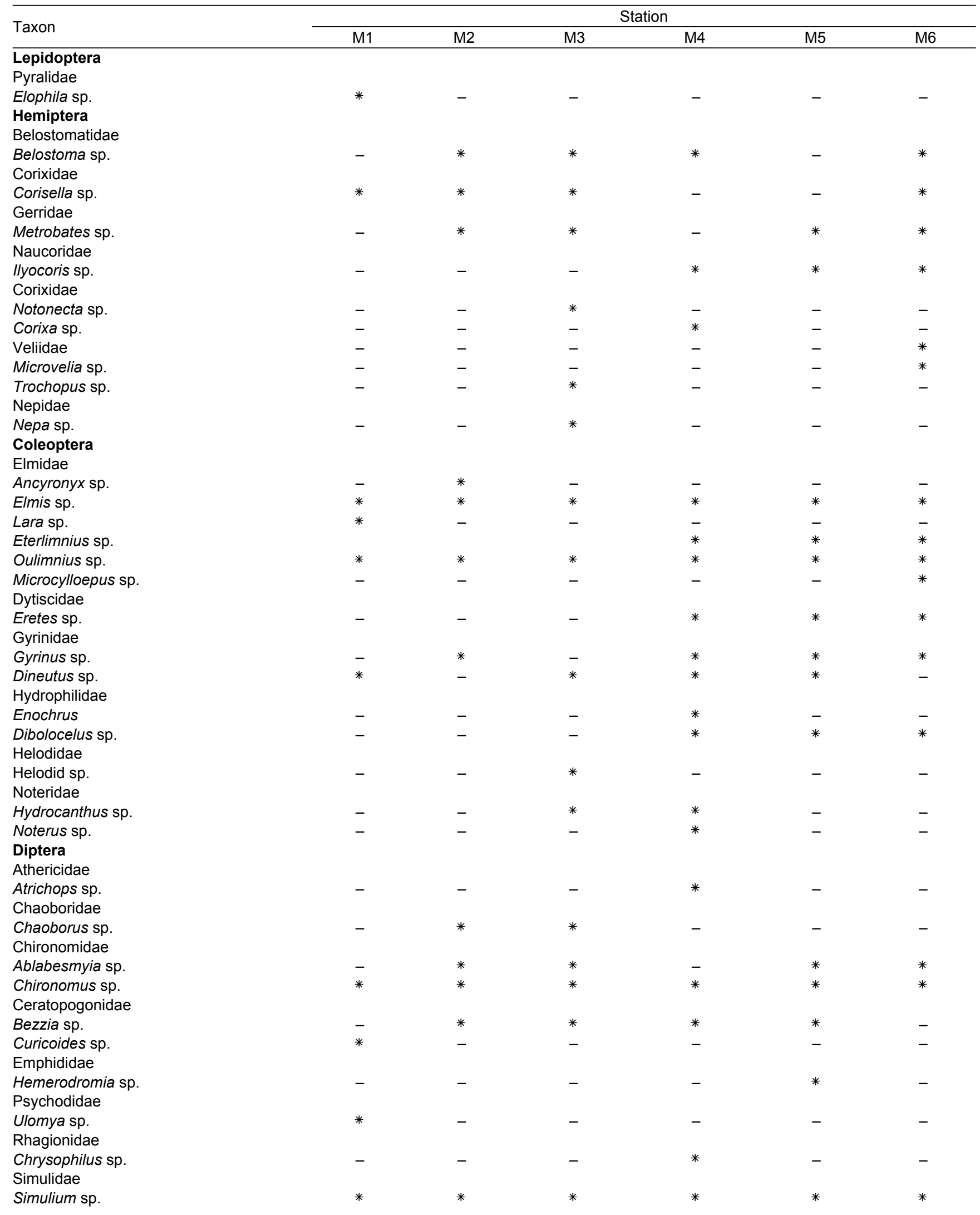


Appendix: (cont.)

\begin{tabular}{|c|c|c|c|c|c|c|}
\hline \multirow{2}{*}{ Taxon } & \multicolumn{6}{|c|}{ Station } \\
\hline & M1 & M2 & M3 & M4 & M5 & $\mathrm{M} 6$ \\
\hline \multicolumn{7}{|l|}{ Tipulidae } \\
\hline Antocha sp. & * & * & - & - & - & - \\
\hline $\begin{array}{l}\text { Pedicia sp. } \\
\text { Tabanidae }\end{array}$ & * & * & - & * & - & - \\
\hline Chrysops sp. & - & - & * & - & - & - \\
\hline
\end{tabular}

